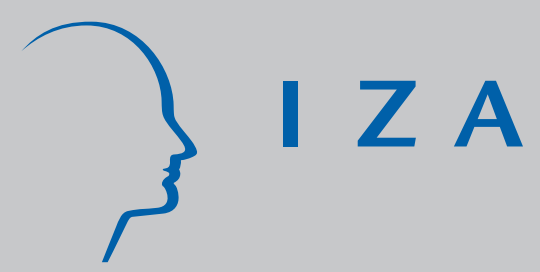

IZA DP No. 1022

Population Prospects and the Determination of a Debt-Sharing Rule between Seceding Regions

Philippe Cattoir

Frédéric Docquier

February 2004 


\title{
Population Prospects and the Determination of a Debt-Sharing Rule between Seceding Regions
}

Philippe Cattoir

European Commission

Frédéric Docquier

CADRE, University of Lille 2,

IWEPS and IZA Bonn

\section{Discussion Paper No. 1022 \\ February 2004}

\author{
P.O. Box 7240 \\ 53072 Bonn \\ Germany
}

Phone: +49-228-3894-0

Fax: +49-228-3894-180

Email: iza@iza.org

Any opinions expressed here are those of the author(s) and not those of the institute. Research disseminated by IZA may include views on policy, but the institute itself takes no institutional policy positions.

The Institute for the Study of Labor (IZA) in Bonn is a local and virtual international research center and a place of communication between science, politics and business. IZA is an independent nonprofit company supported by Deutsche Post World Net. The center is associated with the University of Bonn and offers a stimulating research environment through its research networks, research support, and visitors and doctoral programs. IZA engages in (i) original and internationally competitive research in all fields of labor economics, (ii) development of policy concepts, and (iii) dissemination of research results and concepts to the interested public.

IZA Discussion Papers often represent preliminary work and are circulated to encourage discussion. Citation of such a paper should account for its provisional character. A revised version may be available on the IZA website (www.iza.org) or directly from the author. 
IZA Discussion Paper No. 1022

February 2004

\section{ABSTRACT}

\section{Population Prospects and the Determination of a Debt-Sharing Rule between Seceding Regions*}

This paper investigates one of the most important financial issues arising from a secession or a country partitioning namely the sharing of the national public debt. Extending Drèze's distributive neutrality condition, we use the generational accounting technique and propose a dynamic debt-sharing criterion which takes into account both the true debt future generations inherit and their contributive capacity. The equivalence with Drèze's static rule is only obtained on the balanced growth path, and in the absence of initial regional debt. An application of our criterion to the Belgian case offers striking results.

JEL Classification: $\quad \mathrm{H} 60, \mathrm{H} 77$

Keywords: $\quad$ public debt, secession, generational accounting

Corresponding author:

Frédéric Docquier

CADRE

University of Lille 2

1 Place Déliot

50984 Lille

France

Email: f.docquier@skynet.be

\footnotetext{
* This paper presents research results of the Belgian Program on Interuniversity Poles of Attraction initiated by the Belgian State, Prime Minister's Office, Science Policy Programming. The authors are grateful to R. Deschamps, J. Drèze, M. Marchand, H. Tulkens for their invaluable comments and M. Sobrie and M. Everaerts (Belgian National Institute of Statistics) for their statistical support. We also thank two anonymous referees for their helpful suggestions. The views and analysis presented here are the sole responsibility of the authors. For the first author, this article is presented in personal capacity and does not necessarily reflect the views of the European Commission.
} 


\section{Introduction}

Among the various forms of decentralisation, one is particularly important due to its political, social and economic consequences, namely the case of secession by a regional entity. Though extreme as a decentralisation process, it is not unusual in today's world: the dramatic crisis in former Yugoslavia and recent secessions in the former Soviet Block demonstrate the dynamism of nationalism in contemporary societies. ${ }^{\mathrm{i}}$

The aim of this article is to study more closely one of the most important financial issues arising from secession: the sharing of the (national/federal) public debt among the regions of the previous state.

Most of the criteria discussed in the literature or used in actual secessions are not based on efficiency or equity but rather on short-term political feasibility arguments. Our main objective here is to develop an approach based on equity-efficiency criteria. Extending the seminal contribution of Drèze (1993), we propose a debt-sharing rule that annihilates the distributional incentives for a region to secede. Therefore, the secession would only be motivated by prospects of efficiency gains. Our criterion is based on the generational accounting technique, focusing on the net fiscal burden (called generational account) that each individual must pay to the state over his whole lifetime. More precisely, we determine a formula that shares the debt between the regions in such a way that both current and future generations' net burdens are affected in equal proportions after the secession has occurred. Our distributive neutrality criterion thus aims at reproducing in the future the generational account ratios observed among the regions at the time of secession.

Our rule takes into account the dynamic features of public finances, which is very important when public debt has to be shared. In a static context such as Drèze's, when a long-run budgetary constraint is applied the share each region receives not only depends on the distributive neutrality criterion but also on the timing of budgetary initiatives, i.e. on the objectives in terms of reduction 
of the public debt ratio. In a dynamic context such as the one developed here, the debt-sharing rule also crucially depends on a political decision, namely the relative tax treatment to be given to current and future generations. Indeed, since public debt is an important component of intergenerational transfers, the time-span set to reimburse the debt directly affects the amount of intergenerational transfers. When it is limited in time, current generations bear most of the public debt burden and the richer region will receive a larger share of the debt. When, on the contrary, debt reimbursement is left to future generations debt shares will tend to be larger for regions benefiting from better long-term prospects.

The rest of this paper is organised as follows. In the second section, we present some of the criteria discussed in the literature (or used in actual secessions) and consider the need for a dynamic approach to debt-sharing. In the third section, we present our criterion. We start by a description of the generational accounting-based technique used to compute the debt shares of the regions before showing how the political decision regarding the debt reimbursement affects the debt-sharing formula. Last, we show that Drèze's static rule may be seen as a particular case of our general approach, at least under some stationarity conditions. Section 4 presents an illustration for Belgium.

\section{Debt-sharing criteria}

A secession situation often takes place in a very tense political environment and can in some cases lead to a war situation, such as in Yugoslavia, for instance. Therefore, in the negotiations paving the way to an overall settlement swiftness and ease of decision-making and decisionimplementation are likely to be favoured over fine-tuned processes that are long and difficult to implement. In particular, when it comes to discussing public debt sharing, easily quantifiable and understandable variables are often preferred to complex theoretically-based formulae. In 1993, 
Drèze proposed a simple criterion which has the great advantage of being theoretically founded. However it seems only pertinent in a hypothetical stationary economy.

Let us briefly summarise the literature on debt-sharing and the interest of a dynamic approach.

Easily quantifiable and understandable rules. Among the variables that are commonly used, the population and gross regional product (GRP) or domestic product are certainly the most important ones. These criteria can be qualified as "politically sustainable" since they offer the easy, generally acceptable, solutions which politicians tend to favour. ${ }^{\mathrm{ii}}$ However, these criteria often have no theoretical basis.

Another politically sustainable debt-sharing rule, proposed by Deschamps (1993), recommends sharing the national debt in such a way that the regional deficit ratio (in \% of GRP) remains unchanged for all the regions after secession. In the case where initial deficit-GRP ratios are identical, this criterion consists in sharing public debt according to the ratios of the GRPs on national GDP. Deschamps' proposition offers the advantage of simplicity and easy implementation but it ignores longer-term regional dynamics linked to different growth paths and demographics or to a process of debt reduction.

A significantly different approach is based on the history of the debt build-up. This "historical criterion" requires a comparison of the regional contributions to the national budget in terms of revenues and primary expenditures. Two particular problems can be emphasised with respect to this approach. The first is practical and relates to the limited availability of historical regional budgetary data in most countries. ${ }^{\text {iii }}$ The second is of a more political nature: the historical criterion ignores the political process leading to the debt creation and confers the responsibility of the (past) debt creation to current generations, regardless of the environment in which the debt was built.

The BDN rule. Drèze (1993) proposed a last important criterion. It is, to the best of our knowledge, the only debt-sharing mechanism that is based on a solid theoretical foundation. The 
principle advocated by Drèze is simple: secession should not affect the aggregate transfers between the seceding region and the rest of the nation. In other words, the decision to secede should only be motivated by efficiency considerations, not by the perspective of a "free lunch" resulting from lower transfers to the rest of the pre-existing State. The criterion requires that no citizen be made better- or worse-off on account of the secession itself (distributive neutrality). In this perspective, secessions would ultimately be Pareto improving institutional changes.

Drèze's rule uses budgetary aggregates as a convenient summary characterisation of interregional transfers. To clarify his results, let us denote by $P B^{i}(i=1, \ldots, I)$ and $P B^{n}$ the regional and national budgetary primary balances (one thus has $\left.P B^{n}=\sum_{i} P B^{i}\right)^{\text {iv }}$, by $B^{n}$ the national public debt to be shared and by $r$ the interest rate. Assume for simplicity that primary balances are all positive and that there is neither economic growth nor inflation.

In such a case, the budgetary policy is sustainable if it does not lead to an increase in the public debt over time, i.e. if $r B^{n}-P B^{n}=0$. If this condition holds, Drèze demonstrates that "budgetary distributive neutrality" (BDN) requires that each region be given a share of the national debt $\left(\delta^{i}\right)$ corresponding to the share of its primary budget balance in the national budget balance ${ }^{\mathrm{v}}$, i.e. $\delta^{i}=P B^{i} / P B^{n}$. This rule ensures that each region should be able to maintain the same level of spending and receipts without new debt creation after the secession occurs. Indeed, denoting the post-secession regional debt by $B^{i}$, one gets:

$$
\begin{aligned}
\Delta B^{i} & =r \delta^{i} B^{n}-P B^{i}=r \frac{P B^{i}}{P B^{n}} B^{n}-P B^{i} \\
& =\frac{P B^{i}}{P B^{n}}\left[r B^{n}-P B^{n}\right]=0
\end{aligned}
$$

In this perspective, the same level of receipts and expenditures can be maintained in each region after the secession. Consequently, one observes the same interregional transfers as before. 
This debt sharing rule can also be used if the initial budgetary policy is unsustainable, i.e. if $r B^{n}-P B^{n}>0$. In that case, defining a sustainable-equivalent policy can be seen as a pre-condition for the derivation of the BDN sharing rule: it requires multiplying the national primary balance by a factor $\pi>1$ such that budget balance is obtained (i.e. $r B^{n}-\pi P B^{n}=0$ ). The BDN rule $\left(\delta^{i}=P B^{i} / P B^{n}\right)$ then comes into play: it means that each region receives a debt-share requiring an equiproportional effort to make its policy sustainable (multiplying pre-secession regional primary surplus by a factor $\pi$ ). Consequently, the ratios of regional primary surpluses are unchanged after the secession and the post-secession policy becomes sustainable:

$$
\Delta B^{i}=r \delta^{i} B^{n}-\pi P B^{i}=\frac{P B^{i}}{P B^{n}}\left[r B^{n}-\pi P B^{n}\right]=0
$$

Toward a dynamic extension. Our purpose is to provide a dynamic extension of Drèze's rule. The essence of the argument is simple. Drèze's rule is essentially static and just aims at allowing each region to reproduce (after a possible correction for sustainability) the current level of aggregate receipts and expenditures after a secession. Nevertheless, we do not live in a stationary environment. Economic or demographic changes affect taxes and needs over time (sometimes without voluntary policy changes). ${ }^{\mathrm{vi}}$ Consequently, a neutral sharing rule should take into account expectations on these future needs and means.

This problem can be illustrated by considering a two-period representation. Assume that the current policy generates a primary balance of $P B_{0}^{i}$ today and $P B_{1}^{i}$ in the second period. With a constant interest rate, imposing a sustainability constraint (the national public debt at the end of the second period must be equal to the current level) requires adjusting primary balances in the following way:

$$
\Delta B^{n}=r(2+r) B^{n}-\pi_{0}(1+r) P B_{0}^{i}-\pi_{1} P B_{1}^{i}=0
$$

where the pair $\left(\pi_{0}, \pi_{1}\right)$ represents one possible combination of efforts at the national level. 
In that simple framework, the BDN sharing rule becomes more complex. Formally, each region is asked to carry out an equiproportional effort if its share of debt equals the following ratio based on regional and national weighted sums of primary surpluses ${ }^{\mathrm{vii}}$ :

$$
\delta_{i}=\frac{\pi_{0}(1+r) P B_{0}^{i}+\pi_{1} P B_{1}^{i}}{\pi_{0}(1+r) P B_{0}^{n}+\pi_{1} P B_{1}^{n}}
$$

It clearly appears that this dynamic BDN rule depends on future regional primary balances $\left(P B_{1}^{i}\right)$ as well as on a policy choice, i.e. the combination of current and future efforts $\left(\pi_{0}, \pi_{1}\right)$. Hence, our objective is to evaluate the impact of economic and demographic evolutions, as well as the impact of policy choices, on the BDN shares. For this purpose, we use generational accounting, a methodology that takes into account the long-run needs and means of nations. We then generalise Drèze's proposals in a dynamic set-up based on this technique.

Criticisms of the BDN rule. Unsurprisingly, the BDN strategy is likely to raise some problems. The result of the BDN rule can be politically unacceptable if the secession is partly motivated by the fact that the (richer) seceding regions perceive interregional transfers to be too high and wish to reduce the size of their contributions. However, in many cases, autonomy is seen as a value per se, independently of financial transfers - witness the case of Quebec, a net recipient of transfers in Canada, or Slovakia, the poorest region in the former Czechoslovakia.

Further, in a particular context, such as that prevailing in the European Union, it is doubtful that a particular region could gain its full independence without the agreement of the other regions of the pre-existing State, which would almost certainly require some kind of distributive neutral debtsharing. Implementing any other rule, against the will of the poorer regions, would indeed create an unwelcome precedent for EU countries where richer regions aspire to greater autonomy and thus lead to a strong international opposition. ${ }^{\text {viii }}$ 
Another debate arises from the perception that some of the interregional transfers might result from free-riding behaviour or less rigorous policies in recipient regions. ${ }^{\text {ix }}$ In these cases a BDN rule would in fact reproduce "unfair" transfers in the long run. The existence of such unfair transfers is, however, difficult to prove and even more difficult to measure. In our approach we take as an assumption that all transfers are fair and result from objective factors. Though questionable, it seems to us that this approach is the only reasonable one. Correcting the transfers for some kind of "unfairness" would lead to ad hoc rules and reduce the credibility of the results.

\section{A generational accounting approach}

The key idea of generational accounting is to summarise in one figure the expected net discounted amount of money that the representative agent of each generation must pay to the state during its lifetime. ${ }^{\mathrm{x}}$ In this approach the net taxes are discounted on the basis of an exogenous interest rate and weighted by the survival probabilities.

Generational accounts are computed on the basis of statistical data collected for a period of reference, $t$. Since our purpose is to assess what is to be paid in the future, net taxes paid by present generations before period $t$ are not evaluated here, i.e. the technique is purely prospective.

\subsection{Generational accounts}

More formally, the generational account of one representative agent born in period $k$, in region $i$, and evaluated at time $t$ is given by

(1) $\quad n_{t, k}^{i}=\sum_{s=t}^{k+D} \frac{T_{t, s}^{i} p_{t, s}^{i}}{(1+r)^{s-t}}$ 
where $n_{t, k}^{i}$ denotes the generational account of generation $k$ in region $i(i=1, \ldots, I), T_{t, s}^{i}$ is the net tax which will be paid by the remaining members of generation $k$ in period $s \geq t, p_{t, s}^{i}$ is the probability of being alive in period $s$ given that the individual is alive in $t, r$ is the exogenous discount rate and $D$ is the age limit. The net tax $T_{t, s}^{i}$ takes into account all the taxes and transfers attached to each age group as well as other taxes and primary public expenditures which are shared proportionately to the population size of the nation (if taken from the federal budget) or the region (if taken from the regional budget). It should be noted that $n_{t, k}^{i}$ can be positive or negative depending on the age structure of taxes and transfers.

The following assumptions are made for prospective purpose: (i) the interest rate is constant over time, (ii) the survival probabilities are those observed in period $t$, (iii) the rate of productivity growth is constant over time and equal across regions.

In addition, the basic Auerbach-Kotlikoff methodology suggests that regional age-specific net taxes evolve with productivity growth for current generations. This means that the net tax paid by a thirty years old agent in 10 years is exactly $(1+g)^{10}$ times the net tax paid by a thirty years old agent today, $g$ being the rate of growth. This assumption is very convenient but implies that all the budgetary efforts required by long run debt sustainability are transferred onto future generations. In other words, the net taxes of current living generations cannot be questioned in the classical Auerbach-Kotlikoff approach. ${ }^{\mathrm{xi}}$ An alternative approach, which we explore later, could be to equiproportionately modify the net taxes levied on current generation by a factor $\pi$ (to keep similar notations as in section 2), lower or higher than unity.

We assume for the moment that $n_{t, k}^{i}$ in equation (1) represents the generational account under this classical approach. Multiplying generation $k$ 's account by the size of this generation in period $t$, $P_{t, k}^{i}$, one obtains the net aggregate lifetime tax of generation $k$ in region $i$ : 


$$
N_{t, k}^{i}=n_{t, k}^{i} P_{t, k}^{i}
$$

\subsection{Intertemporal budget constraints}

In order to derive future generations' accounts, the use of intertemporal budget constraints is necessary. In a purely national government there would be a single national intertemporal budget constraint implying national financing for all expenditures. In a multiregional context, such as here, a budgetary constraint must be defined for each region.

This constraint stipulates that the regional debt, including the share of national debt transferred $\left(\delta^{i} B_{t}^{n}\right)$ to region $i$, must be reimbursed one day. The true debt bequeathed to future generations in region $i, T D_{t}^{i}$, is given by the sum of the current regional debt $\left(B_{t}^{i}\right)$ and the share of national debt transmitted to region $i$ minus the net expected contributions of present generations in region $i$ (which may be negative):

$$
T D_{t}^{i}=B_{t}^{i}+\delta^{i} B_{t}^{n}-\sum_{s=0}^{D} N_{t, t-s}^{i}
$$

However, fiscal changes might modify the generational accounts of current generations in the future. Suppose that the net taxes in region $i$ are modified by a proportional factor $\pi_{P}^{i}$. The true debt would then become

$$
T D_{t}^{i}=B_{t}^{i}+\delta^{i} B_{t}^{n}-\pi_{P}^{i} \sum_{s=0}^{D} N_{t, t-s}^{i}
$$

It is useful to derive the average generational account of individuals of future generations. This can be done by assuming that each agent will pay an equal discounted net tax corrected for productivity growth. In discounted and growth-corrected terms, the average tax of future generations in region $i$, $\bar{n}^{i}$ corresponds to: 


$$
T D_{t}^{i}=\bar{n}^{i} \sum_{s=1}^{\infty} \frac{P_{t+s, t+s}^{i}(1+g)^{s}}{(1+r)^{s}}=\bar{n}^{i} W_{t}^{i}
$$

where $P_{t+s, t+s}^{i}$ denotes the initial size of future generation $t+s ; W_{t}^{i}$ may be defined as the weight - in efficiency units - of future generations in region $i$. Note that $\bar{n}^{i}$ can also be expressed as a fraction $\pi_{F}^{i}$ of the tax borne by the newborns in region $i, \bar{n}^{i}=\pi_{F}^{i} n_{t, t}^{i}$. The intertemporal budgetary constraint in region $i$ can then be rewritten as

$$
\text { (4) } \quad \pi_{F}^{i} W_{t}^{i} n_{t, t}^{i}=B_{t}^{i}+\delta^{i} B_{t}^{n}-\pi_{P}^{i} \sum_{s=0}^{D} N_{t, t-s}^{i}
$$

For a given proportion of the national debt received, $\delta^{i}$, there is an infinity of combinations $\left(\pi_{P}^{i}, \pi_{F}^{i}\right)$ which allows balancing the budget in each region $i$. For example, for $\pi_{P}^{i}$ equal to unity (which corresponds to unchanged entitlements for the living generations), $\pi_{F}^{i}$ is the only endogenous variable (this scenario is labelled FG henceforth, standing for future generations). This is the technical assumption proposed by Auerbach and Kotlikoff to evaluate the long-run sustainability of the current policy. ${ }^{x i i}$ A contrario, if $\pi_{F}^{i}$ is set equal to one, future generations' net taxes are the same as current net taxes and $\pi_{P}^{i}$ becomes the only endogenous variable. In this case budgetary adjustments affect the current living generations only (in what follows LG stands for living generations). Finally, equation (4) can be solved under the constraint $\pi_{P}^{i}=\pi_{F}^{i}$, implying that living and future generations are treated equally (this scenario is labelled by EQ henceforth).

\subsection{Distributively neutral debt sharing rules}

We first focus on distributive neutrality across regions before specifying the impact of intergenerational budgetary adjustment decisions on the debt-sharing mechanism. 
Definition. A distributively neutral sharing-rule is a set $\left(\delta^{1}, \ldots, \delta^{i}, \ldots, \delta^{I}\right)$ of debt shares such that (i) living generations' accounts reveal the same regional discrepancies as the ones prevailing under the assumption of unchanged future net taxes and (ii) future generations' accounts reveal the same regional discrepancies as the ones observed for newborns under the same assumption.

The regional discrepancies can be measured either by the difference between regional generational accounts in absolute terms or by the ratio of generational accounts. In what follows, we use the second approach. However, in order to respect the intertemporal budget constraints, a distributively neutral debt-sharing rule can only be reached through a proportional transformation of the current and future generational accounts:

Proposition 1. The set of distributively neutral debt-sharing rules is the set of pairs $\left(\pi_{P}^{i}, \pi_{F}^{i}\right)$ such that (i) $\pi_{F}^{i}=\pi_{F}$, (ii) $\pi_{P}^{i}=\pi_{P}$ for all $i$, (iii) $\sum_{i} \delta^{i}=1$ and (iv) respecting the regional intertemporal budget constraints (4).

Condition (i) implies that the ratios of the future generations' accounts are identical to the ratios observed for the newborns across regions. Condition (ii) implies that these ratios are also maintained for living generations. Condition (iii) ensures that national public debt is fully distributed among the regions. Finally, condition (iv) guarantees the long-run sustainability of the debt sharing.

Note that the aggregation of condition (iv), combined with condition (iii) gives the national intertemporal budget constraints: 


$$
\pi_{F} \sum_{i \in I} W_{t}^{i} n_{t, t}^{i}=\sum_{i \in I} B_{t}^{i}+B_{t}^{n}-\pi_{P} \sum_{i \in I} \sum_{s=0}^{D} N_{t, t-s}^{i}
$$

Since an infinity of pairs $\left(\pi_{P}^{i}, \pi_{F}^{i}\right)$ respecting conditions (i)-(iv) exist, there is also an infinity of distributively neutral sharing-rules according to our definition. We present here two extreme cases (the FG sharing-rule where $\pi_{P}=1$ and the LG sharing-rule where $\pi_{F}=1$ ) as well as an intermediate case (the EQ sharing rule with $\pi_{P}=\pi_{F}$ ).

\subsubsection{FG debt-sharing rule}

The FG debt-sharing rule satisfies the "unchanged net taxes" assumption presented above. In this case, one looks for the combination $\left(\pi_{P}, \pi_{F}\right)=\left(1, \pi_{F G}\right)$ which leaves all budgetary adjustments to future generations. The system contained in the above proposition sums up as a system of $I+1$ equations with one budgetary constraint for each region and one aggregated national budgetary constraint (5). The $I+1$ unknown variables are the regional shares of the debt, $\delta^{i}$, and $\pi_{F G}$, an indicator of intergenerational adjustment (keeping the net taxes unchanged for living generations, the net taxes of future generations must be multiplied by the factor $\pi_{F G}$ ). From (5), one gets

$$
\pi_{F G}=\frac{\sum_{i \in I} B_{t}^{i}+B_{t}^{n}-\sum_{i \in I} \sum_{s=0}^{D} N_{t, t-s}^{i}}{\sum_{i \in I} W_{t}^{i} n_{t, t}^{i}}
$$

where $\pi_{F G}$ clearly depends on the true debt bequeathed to future generations.

Using the regional budgetary constraints it is then possible to obtain the regional debt-shares

(7) $\quad \delta_{F G}^{i}=\frac{\pi_{F G} W_{t}^{i} n_{t, t}^{i}+\sum_{s=0}^{D} N_{t, t-s}^{i}-B_{t}^{i}}{B_{t}^{n}}$ 
The solution to this system is unique. It shows that the share that a region obtains is a positive function of its current and future generations' accounts and a negative function of the amount of its initial debt.

\subsubsection{LG debt-sharing rule}

In the case of the LG sharing rule one looks for the combination $\left(\pi_{P}, \pi_{F}\right)=\left(\pi_{L G}, 1\right)$ which leaves all budgetary adjustments to current (living) generations. The $I+1$ unknown variables are the regional debt-shares, $\delta^{i}$, and $\pi_{L G}$, an indicator of intergenerational adjustment (keeping the net taxes unchanged for future generations, the net taxes of living generations must be multiplied by the factor $\pi_{L G}$. From (5), one obtains

$$
\pi_{L G}=\frac{\sum_{i \in I} B_{t}^{i}+B_{t}^{n}-\sum_{i \in I} W_{t}^{i} n_{t, t}^{i}}{\sum_{i \in I} \sum_{s=0}^{D} N_{t, t-s}^{i}}
$$

Using the regional budgetary constraints it then follows that

(9) $\quad \delta_{L G}^{i}=\frac{W_{t}^{i} n_{t, t}^{i}+\pi_{L G} \sum_{s=0}^{D} N_{t, t-s}^{i}-B_{t}^{i}}{B_{t}^{n}}$

This is a unique solution different from the one obtained in the FG case. Indeed, any additional budgetary effort or room for manoeuvre is imposed on (or benefits) the living generations proportionately to their relative generational accounts. In the FG approach, budgetary efforts or gains affect the future generations but not newborns generational accounts.

\subsubsection{EQ debt-sharing rule}

In the EQ debt-sharing rule, the budgetary effort is equally shared between living and future generations. All generations are treated equally. It corresponds to the combination 
$\left(\pi_{P}, \pi_{F}\right)=\left(\pi_{E Q}, \pi_{E Q}\right)$ solving the aggregate budgetary constraint (5). The $I+1$ unknown variables are the regional debt-shares, $\delta^{i}$, and $\pi_{E Q}$, which can be interpreted as a general indicator of budgetary unsustainability. From (5), one obtains

(10) $\pi_{E Q}=\frac{\sum_{i \in I} B_{t}^{i}+B_{t}^{n}}{\sum_{i \in I} \sum_{s=0}^{D} N_{t, t-s}^{i}+\sum_{i \in I} W_{t}^{i} n_{t, t}^{i}}$

Using the regional budgetary constraints, we then derive

$$
\delta_{E Q}^{i}=\frac{\pi_{E Q}\left[W_{t}^{i} n_{t, t}^{i}+\sum_{s=0}^{D} N_{t, t-s}^{i}\right]-B_{t}^{i}}{B_{t}^{n}}
$$

This is another solution of the debt-sharing problem.

\section{Comparison with static rules}

The budgetary constraint (5) can be rewritten as

$$
\sum_{i \in I} B_{t}^{i}+B_{t}^{n}=\pi_{F} \sum_{i \in I} W_{t}^{i} n_{t, t}^{i}+\pi_{P} \sum_{i \in I} \sum_{s=0}^{D} N_{t, t-s}^{i}
$$

The first term on the right side of the equality sign measures the present value of net taxes paid by future generations. The second term corresponds to the present value of net taxes paid by living generations. The sum of these two terms is the present value of the future primary balances of the nation. The budget constraint becomes:

$$
\sum_{i \in I} B_{t}^{i}+B_{t}^{n}=\sum_{v=t}^{\infty} \frac{P B_{v}^{n}}{(1+r)^{v-t}}
$$

Using (3), the same reasoning allows rewriting 


$$
\delta^{i}=\left(\sum_{v=t}^{\infty} \frac{P B_{v}^{i}}{(1+r)^{v-t}}-B_{t}^{i}\right) /\left(\sum_{v=t}^{\infty} \frac{P B_{v}^{n}}{(1+r)^{v-t}}-\sum_{i \in I} B_{t}^{i}\right)
$$

where $P B_{t}^{n}\left(P B_{t}^{i}\right)$ is the primary balance of the nation (of region $i$ ) at the date $t$.

Any sharing rule must be such that the share received by each region equals the ratio of the present value of future regional primary imbalance to the present value of national primary imbalances, corrected by initial regional debt sizes. This is not a property of distributively neutral sharing rules but a consequence of the regional and national intertemporal budgetary constraints. There is an infinity of sharing rules satisfying this sustainability condition depending on the sequence of future primary imbalances imposed on each region. Our distributive neutral rules form a subset of all these sustainable sharing rules.

Let us now show that this distributively neutral subset contains a unique balanced growth rule and that this balanced growth solution corresponds to Drèze's static proposal. This result can be rewritten as follows:

Proposition 2. On the balanced growth path without initial regional debt the only distributively neutral debt-sharing rule when current net taxes are compatible with the intertemporal budget constraint is given by the ratio of primary balances $\delta^{i}=P B_{t}^{i} / P B_{t}^{n}$ observed at time $t$.

To show this result one has to consider a population growing at a constant rate, $m$, with a constant demographic structure, i.e. the share of each regional age group is constant over time. Then, if individual net taxes are permanently adapted to economic growth, $g$, primary imbalances which measure the sum of net taxes raised on the entire population, evolve according to these two rates: $P B_{v}^{i}=P B_{t}^{i}(1+g)^{v-t}(1+m)^{v-t}$ for all $i$ and $v \geq t$. This situation refers to a balanced growth path. In 
this case the infinite sums at the numerator and denominator of equation (12) are geometric sequences with identical geometrical ratios. In the absence of initial regional debt, the unique balanced growth-sharing rule is given by the ratio of primary imbalances observed in period $t$.

To show that this solution corresponds to a feasible sharing rule, two problems must be solved. Is this rule compatible with the intertemporal budget constraints? And is this sharing rule distributively neutral?

These two questions are interrelated. Indeed, in budgetary terms, the sustainability condition implies that $P B_{t}^{n}=(r-m-g) B_{t}^{n}$. In generational accounting terms, it implies that it must be possible to guarantee the same generational accounts for future generations as for the newborns of time $t$. Analytically, the balanced growth path is compatible with the intertemporal budgetary equilibrium if and only if equation (5) is satisfied with $\left(\pi_{P}, \pi_{F}\right)=(1,1)$. The distributive neutrality thus automatically applies.

It should be noted that this balanced growth solution is unique since any other pair of $\left(\pi_{P}, \pi_{F}\right)$ that would respect the budgetary constraint would lead to a change in the future generations net taxes compared to the newborns and, consequently, in the primary balances, which would be contrary to the balanced growth hypothesis.

\section{Illustration for Belgium}

\subsection{Evaluating primary imbalances}

The first step of our work consists in building consolidated regional budgets for Belgium. This requires eliminating all transfers between institutions, and disaggregating all national expenditures and revenues into regional components. 
Some regional data ${ }^{x i i i}$ may easily be computed from the budgets of decentralised Belgian institutions (mainly Regions and Communities). The regional disaggregation of federal taxes and spending as well as social security aggregates is more complex. Here we follow the methodology of Beine et al. (1998). It is usually possible to collect information about age and regional distributions of taxes and transfers. However, for the taxes and transfers which are non specific to an age group or to a region, we assume that they are distributed in equal amounts over the national population (if taken from the federal budget), or over the regional population (if taken from the regional budget).

We obtain the following results: the consolidated primary surplus of public authorities (excluding local authorities) reaches $6,16 \%$ of GDP in $1999 .{ }^{\text {xiv }}$ The regional distribution of this surplus reveals that Flanders experiences a very high surplus of $5.64 \%$ of (national) GDP compared to $0.23 \%$ for Wallonia and $0.29 \%$ for Brussels. The corresponding primary balance- GRP ratios are respectively $9.24 \%, 0.75 \%$ and $3.40 \%$.

The difference in regional primary balance to GRP ratios can be explained by a mix of economic and demographic factors. Variations in GRP explain higher net taxes in Flanders compared to Wallonia. In 1999, the contribution of Flanders and Wallonia to the national GDP was $57.1 \%$ and $23.8 \%$ respectively, compared with their share in the population $(58.1 \%$ and $32.7 \%)$. Unsurprisingly, this difference in economic development is reflected in the level of taxes per capita. $^{\mathrm{xv}}$ Wallonia also benefited from explicit interregional equalization transfers and implicit transfers through the social security national system. Cattoir and Docquier (1999) estimated a net social security transfer amounting to $0.73 \%$ of the national GDP in 1999.

On the other hand, the situation of Brussels is more complex. For linguistic reasons, the region of Brussels (161 $\mathrm{Km}^{2}$, less than $0.5 \%$ of Belgium) is limited to the center of Brussels, while the hinterland of the city is included in the other two regions. The low ratio of primary balance to GRP is explained not by a lower economic development ${ }^{\mathrm{xvi}}$, but by demographic factors. Each day, more 
than 330,000 commuters (i.e. $55 \%$ of the workforce) come into the Brussels region to work, but pay taxes in the other two regions.

\subsection{Computing generational accounts for current generations}

The second step of our analysis consists in computing generational accounts for current generations.

Using the age profiles of net tax, it is possible to infer the net burden current generations must still bear for the rest of their life. This is done by assuming that per capita revenues and expenditures in each region are adapted to the national real growth rate and that future survival probabilities for members or each generation correspond to those observed today. For our purpose we consider a constant real growth rate of $1.5 \%$ per year and a real interest rate of $5 \%$. ${ }^{\text {xvii }}$

The aggregate regional sharing of revenues and expenditures for current generations can easily be

computed. ${ }^{\text {xviii }}$ It appears that the private sector pensions and health care (including disability) constitute a higher burden for future generations than the explicit public debt: the future entitlements for current living generations in these two sectors amount to $210.9 \%$ of GDP as compared to $115 \%$ for the federal public debt. However, future revenues in the social security sector approximately equal future entitlements (maintaining current federal transfer rules) while a primary surplus is observed for the public sector excluding social security. This surplus must be compared to the current debt level and current debt service to be financed in the future. ${ }^{\text {xix }}$

Using the date described above, we also compute the newborns' generational accounts. We obtain an average discounted lifetime net transfer, $n_{t, t}^{a}$, of Euro 46,430 for newborns (see table 1 below). ${ }^{\mathrm{xx}}$ However, this net transfer is $30 \%$ higher in Wallonia (Euro 60,585), 23\% higher in Brussels (Euro 57,412) and 53\% lower in Flanders (Euro 21,344). 
Table 1. Key parameters - Base year 1999 (in thousand of Euro)

\begin{tabular}{|l|c|c|c|c|c|}
\hline & $\begin{array}{c}\text { Initial debt } \\
\left(B_{99}^{i}\right)\end{array}$ & $\begin{array}{c}\text { Population } \\
\left(P_{99}^{i}\right)\end{array}$ & $\begin{array}{c}\text { Total net tax of } \\
\text { living generations } \\
\left(\sum_{s=0}^{D} N_{99,99-s}^{i}\right)\end{array}$ & $\begin{array}{c}\text { Efficency weight } \\
\text { of future } \\
\text { generations } \\
\left(W_{99}^{i}\right)\end{array}$ & $\begin{array}{c}\text { Generation } \\
\text { accounts of } \\
\text { newborns } \\
\left(n_{99,99}^{i}\right)\end{array}$ \\
\hline Wallonia & $7,956,217$ & $3,348,206$ & $76,080,630$ & $20,827,245$ & -60.585 \\
\hline Flanders & $8,891,172$ & $5,942,003$ & $362,531,761$ & $34,052,266$ & -21.344 \\
\hline Brussels & $2,948,644$ & 937,002 & $31,773,207$ & $6,395,306$ & -57.412 \\
\hline Federal & $243,157,816$ & & & & \\
government & $\left(B_{99}^{n}\right)$ & & & & \\
\hline Belgium & $262,953,850$ & $10,227,211$ & $470,385,598$ & $61,274,817$ & -46.430 \\
& & & & & \\
& & & & & \\
\hline
\end{tabular}

\subsection{Debt-sharing and budgetary adjustment}

Before computing budgetary neutral sharing rules, it is worth noting that current generations' efforts at reimbursing public debt imply that future generations will be better off than current ones. Indeed, while the total debt of all levels of government amounts to Euro 262.954 bn (see Table 1), the total present value of net taxes of living generations amounts to Euro 470.386 bn, thereby leaving a negative true debt of Euro -207.432 bn to future generations. In other words, the average net burden of future generations $\left(\bar{n}^{i}\right)$ amounts to Euro -101,600, a transfer 2.19 times greater than that for the current newborns. $^{\text {xxi }}$

In a situation where a true debt of Euro -95 millions $\left(\sum_{i} W_{t}^{i} n_{t, t}^{i}\right)$ would suffice to grant the same treatment to future and living generations, there is no reason to believe that living generations will maintain their efforts for the sole benefit of future generations. 
Therefore, this is where a political decision will have to be made as to the desirable generational imbalance, $\pi_{p}$ or $\pi_{F}$. This will in turn affect the debt sharing. To illustrate this point, note that the shares of net tax levied on living generations in Wallonia, Flanders and Brussels are 0.16, 0.77 and 0.07, respectively, while their shares in $\sum_{i} W_{t}^{i} n_{t, t}^{i}$ are instead $0.54,0.31$ and 0.16 . It then makes a big difference whether the initial imbalance or "margin" of Euro 112.4 millions (i.e. Euro 207.4 millions - Euro 95.0 millions) is shared proportionately among the future generations, among the living generations, or among both living and future generations.

\subsection{Sharing the public debt}

The distributively neutral debt-sharing rules require maintaining the differences in current and future generational accounts while respecting budgetary constraints. Generational accounts for future generations are, respectively, 30\% and 23\% higher in Wallonia and Brussels compared to the average, and 53\% lower in Flanders, figures which will have to remain the same after debt-sharing.

Furthermore, note that in the case of the FG sharing rule $\left(\pi_{p}=1\right)$, the initial imbalance or "margin" only benefits future generations. In the LG sharing rule $\left(\pi_{F}=1\right)$, the whole initial imbalance benefits the living generations, leaving the future generations worse-off than in the FG scenario. In the case of the EQ sharing rule, budgetary adjustments are equiproportionately shared between living and future generations. Results are presented in table 2.

Under the FG sharing rule Flanders would receive a little more than the overall debt $-119.1 \%$ exactly - in case of secession. Assets given to Wallonia and Brussels would amount to $17.7 \%$ and $1.4 \%$ of the public debt, respectively. ${ }^{\text {xxii }}$ Under the LG sharing rule $97.8 \%$ of the overall debt should be assigned to Flanders and $2.6 \%$ to Brussels. Wallonia should receive assets amounting to 
$0.4 \%$ of the national debt. Under the EQ sharing rule Flanders, Wallonia and Brussels would respectively receive $92.3 \%, 4.0 \%$ and $3.7 \%$ of the national public debt.

Table 2 also offers a comparative view of various criteria that can be used to share a public debt. Interestingly, the FG, LG and EQ rules offer results that are quite different from most other methods.

Table 2. Debt-sharing rules under various criteria in 1999 (in \% of the total)

\begin{tabular}{|c|c|c|c|}
\hline & Wallonia & Brussels & Flanders \\
\hline FG sharing rule & -17.7 & -1.4 & 119.1 \\
LG sharing rule & -0.4 & 2.6 & 97.8 \\
EQ sharing rule & 4,0 & 3,7 & 92,3 \\
\hline Deschamps' rule & 6.0 & 5.1 & 88.9 \\
Drèze's BDN rule $^{\mathrm{a}}$ & 15.2 & 6.8 & 78.0 \\
Gross Regional Product & 29.1 & 9.2 & 61.7 \\
Per capita debt-sharing $_{\text {Historical criterion }}^{\mathrm{b}}$ & 32.7 & 9.2 & 58.1 \\
\hline
\end{tabular}

Notes: (a) Cf. Drèze (1993), pp. 304-306, $T=15, d=0.60$. Other parameters correspond to the ones used for the distributive neutrality rules; (b) for 1985, (cf. Van Rompuy, 1988): actual figures would be even less favourable to Wallonia.

Following the distributive neutrality criterion, we show that in order to maintain unchanged generational accounts for both current and future generations compared to the status quo, Flanders should bear most if not even the total of the Belgian public debt in case of secession. This reveals the importance of the current transfers between Regions, but also the enormous loss which most other sharing rules would represent for Brussels and Wallonia following a country partitioning. Indeed, accepting other criteria would simply require higher taxes or lower provision of public goods in these regions than those which would occur within the current institutional framework. 
The political decisions regarding the intergenerational sharing of the initial budgetary imbalance would have heavy consequences for debt-sharing. Leaving the full adjustment to current generations (LG sharing rule) implies that a smaller share of the debt would go to Flanders than what would occur otherwise. On the contrary, leaving the adjustments to future generations (FG sharing rule) would generate a higher debt share for Flanders. These results can be explained by the fact that the share of Flanders in the total net tax of current generations is much higher than its share in future generations accounts due to the expected demographic evolution of this region compared to the others.

\section{Conclusions}

In the past, the world has witnessed many secession and country-partitioning cases. Some have been peaceful, as in Czechoslovakia, while others have resulted in wars, as in Yugoslavia. In the future, other secession cases might arise. Among the possible candidates for a very extended autonomy or secession are regions such as Quebec, Flanders, the Basque Country or Catalonia.

These situations generally lead to enormous political, social and economic disruptions. They also require some rules concerning how to share the national pre-existing debts. Usually, these rules are based on short-term, political considerations. In this perspective, one tends to favour debt-sharing criteria that are easy to understand and to implement, such as a per capita sharing or a sharing based on gross regional products.

Surprisingly, few normative criteria to share a public debt have been developed up to now. This article provides a set of rules based on equity-efficiency considerations inspired by Drèze's (1993) proposal. The distributive neutrality criterion advocated here is a rule that determines how to share the debt in order to maintain unchanged net lifetime taxes for current and future generations in each 
region in case of a secession. Any secession would then arise only for efficiency reasons, not for interregional redistribution considerations.

Adopting this rule could therefore limit international instability by reducing financial incentives for richer regions to secede. In particular, in the European Union context where many regions aspire to a greater autonomy within an already unified economic and monetary union, it provides a fair and transparent principle possibly limiting egoistic (infra-) national aspirations.

The criterion that we propose in this paper is theoretically appealing. However, it does have some shortfalls. First, the determination of age-specific and regional data requires a number of assumptions. Even with reliable statistical data, this might prove a difficulty in implementing the rule in actual cases. Second, the sharing rule strongly depends on regional convergence (or divergence) forecasts not dealt with in this paper. Thirdly, the distributive neutrality used here only focuses on public transfers and not on primary income. Therefore, in terms of fiscal pressure, our criteria are neutral if and only if taxes and transfers evolve with primary incomes in the regions. As for any debt-sharing rule, the need for some kind of mutual insurance mechanism to deal with regional convergence or divergence in primary income and public expenditures and revenues appears. Last, and most importantly, the criterion offers room for fiscal imbalances. When some initial budgetary "margin" exists, a political decision is necessary to determine how to share it among generations. This in turn strongly affects the debt shares of the regions.

An application of the rule to Belgium offers striking results. While the "historical" criterion is likely to lead to a debt share of about $100 \%$ for the poorest region (Wallonia), our distributive neutrality criterion leads to a debt share close to $100 \%$ for the richest region (Flanders). It is unlikely that the distributive neutrality rule would be politically acceptable to the Flemish government in case of secession. But any debt-sharing more favourable to Flanders would imply a situation for future generations in Brussels and Wallonia that would be worse than what would actually occur under a status quo situation. 


\section{References}

Auerbach, A.J., J. Gokhale and L.J. Kotlikoff (1991), "Generational accounts: a meaningful alternative to deficit accounting", NBER Working paper, n $^{\circ} 3589$.

Auerbach, A.J., J. Gokhale and L.J. Kotlikoff (1994), "Generational accounting: a meaningful way to evaluate fiscal policy, Journal of Economic Perspectives, 8, pp. 95-111.

Beine, M., Ph. Cattoir and F. Docquier (1998), "Reformes institutionnelles, solidarité intergénérationnelle et interrégionale", in Cifop (ed.): Actes du colloque des économistes belges de langue française, Charleroi.

Cattoir, Ph. and F. Docquier (1999), "Sécurité sociale et solidarité interrégionale", in F. Docquier (ed.), La solidarité entre Régions. Bilan et Perspectives, De Boeck: Bruxelles.

Dellis, A. and E. Lueth (1998), "Belgium: does fiscal policy cope with debt and aging? A generational perspective", Report of the EU Commission's Directorate General XXI, Liège.

Deschamps, R. (1993), "Perspectives à long terme du fédéralisme belge: solidarités et intérêts communs", paper presented at "Les finances publiques de la Région wallonne", Liège.

Deschamps, R. (1998), "Fédéralisme et partage des compétences fiscales", Reflets et Perspectives de la Vie Economique, XXXVII, pp. 91-100.

Docquier, F. (1999), "La solidarité fiscale et parafiscale en Belgique. Une approche par la comptabilité générationnelle", in F. Docquier (ed.), La solidarité entre Régions. Bilan et Perspectives, De Boeck: Bruxelles.

Drèze, J. (1993), "Regions or Europe: a feasible status, to be discussed", Economic Policy, 17, pp. 266-307.

Feldstein, M. (1995), "Would privatizing social security raise economic welfare?", NBER Working paper, $\mathrm{n}^{\circ} 5281$. 
Gokhale, J., B.R. Page and J.R. Sturrock, 1999, "Generational accounts for the United States: an update", in Auerbach, A.J., L. J. Kotlikoff and W. Leibfritz (ed.), Generational Accounting Around the World, NBER Books, The University of Chicago Press.

Kotlikoff, L.J. (1992), Generational accounting, The Free Press: New York.

Roland, G., T. Vandevelde and Ph. Van Parijs (1999), "Repenser (radicalement?) la solidarité entre régions et nations", in F. Docquier (ed.), La solidarité entre Régions. Bilan et Perspectives, De Boeck: Bruxelles.

Van Parijs, Ph. (1999a), "Y a-t-il une alternative au dualisme des solidarités? L'exemple des soins de santé", in F. Docquier (ed.), La solidarité entre Régions. Bilan et Perspectives, De Boeck: Bruxelles.

Van Parijs, Ph. (1999b), "Rechtvaardig sociaal beleid in een plurinationale federale staat", Mimeo, Université Catholique de Louvain.

Van Parijs, Ph. (1999b), "Du juste partage d'une dette commune", Mimeo, Université Catholique de Louvain.

Van Rompuy, P. (1998), Tien jaar financiële stromen tussen de gewesten", Leuvense Economische Stanpunten, $\mathrm{n}^{\circ} 45$. 


\section{Appendix}

The appendix presents the sensitivity of our sharing rules in the two extreme scenarios (the FG and LG rules). For this purpose, we let the annual rate of growth vary between $1 \%$ and $2 \%$ and we let the annual interest rate vary between $3 \%$ and $6 \%$. Table A.1 and A.2 give the results.

Table A.1. Sensitivity of debt shares to discount and growth rates (LG-rule)

\begin{tabular}{|c|c|c|c|c|c|}
\hline \multirow{3}{*}{ Growth rate } & Interest rate & $3.0 \%$ & $4.0 \%$ & $5.0 \%$ & $6.0 \%$ \\
\hline \multirow{3}{*}{$1.0 \%$} & & & & & \\
& Wallonia & $-6.9 \%$ & $-1.9 \%$ & $0.8 \%$ & $2.4 \%$ \\
& Flanders & $105.7 \%$ & $99.6 \%$ & $96.2 \%$ & $94.2 \%$ \\
& Brussels & $1.2 \%$ & $2.3 \%$ & $2.9 \%$ & $3.4 \%$ \\
\hline \multirow{3}{*}{$1.5 \%$} & Wallonia & $-11.4 \%$ & $-4.1 \%$ & $-0.4 \%$ & $1.7 \%$ \\
& Flanders & $111.1 \%$ & $102.2 \%$ & $97.8 \%$ & $95.2 \%$ \\
& Brussels & $0.4 \%$ & $1.8 \%$ & $2.6 \%$ & $3.2 \%$ \\
\hline \multirow{3}{*}{$2.0 \%$} & Wallonia & $-18.6 \%$ & $-7.1 \%$ & $-2.0 \%$ & $0.7 \%$ \\
& Flanders & $119.6 \%$ & $105.9 \%$ & $99.7 \%$ & $96.4 \%$ \\
& Brussels & $-0.9 \%$ & $1.2 \%$ & $2.3 \%$ & $2.9 \%$ \\
\hline
\end{tabular}

Table A.2. Sensitivity of debt shares to discount and growth rates (FG-rule)

\begin{tabular}{|c|c|c|c|c|c|}
\hline \multirow{3}{*}{ Growth rate } & Interest rate & $3.0 \%$ & $4.0 \%$ & $5.0 \%$ & $6.0 \%$ \\
\hline \multirow{3}{*}{$1.0 \%$} & & & & & \\
& Wallonia & $-72.3 \%$ & $-27.2 \%$ & $-10.5 \%$ & $-1.9 \%$ \\
& Flanders & $186.1 \%$ & $130.9 \%$ & $110.3 \%$ & $99.6 \%$ \\
& Brussels & $-13.8 \%$ & $-3.7 \%$ & $0.2 \%$ & $2.3 \%$ \\
\hline \multirow{3}{*}{$1.5 \%$} & Wallonia & $-144.2 \%$ & $-43.9 \%$ & $-17.7 \%$ & $-5.9 \%$ \\
& Flanders & $273.6 \%$ & $151.3 \%$ & $119.1 \%$ & $104.5 \%$ \\
& Brussels & $-29.4 \%$ & $-7.5 \%$ & $-1.4 \%$ & $1.4 \%$ \\
\hline \multirow{3}{*}{$2.0 \%$} & Wallonia & $-504.2 \%$ & $-74.8 \%$ & $-28.2 \%$ & $-11.1 \%$ \\
& Flanders & $710.0 \%$ & $189.2 \%$ & $132.1 \%$ & $111.0 \%$ \\
& Brussels & $-105.8 \%$ & $-14.3 \%$ & $-3.9 \%$ & $0.1 \%$ \\
\hline
\end{tabular}


${ }^{\mathrm{i}}$ Bookman (1993) refers to thirty-three seceding regions in Asia, Africa, the Middle East, North America, the former Soviet Block and Western Europe.

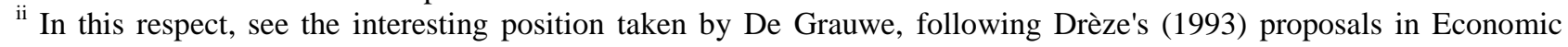
Policy

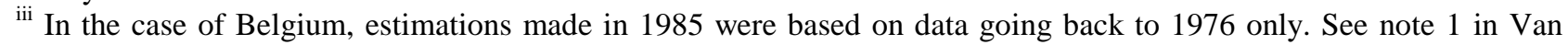
Parijs (1993).

${ }^{\text {iv }}$ It is obviously assumed that the national primary surplus can be divided into regional surpluses.

${ }^{\mathrm{v}}$ The basic rule advocated by Drèze is similar to the one of Deschamps under very specific conditions (budgetary balance at the national level, no initial regional debts, constant debt ratio). However, Drèze's criterion can be easily adapted to specific cases of initial debt and deficit imbalances or debt-ratio constraints.

${ }^{\mathrm{vi}}$ Just think about the effect of ageing on public pension expenditures or the effect of an adverse economic shock on unemployment benefits.

${ }^{\text {vii }}$ Using the same technique than before, one easily checks that $\Delta B^{i}=r(2+r) \delta^{i} B^{n}-\pi_{0}(1+r) P B_{0}^{i}-\pi_{1} P B_{1}^{i}=0$.

viii See Drèze (1993) for an interesting discussion in this respect.

${ }^{\text {ix }}$ See Roland et al. (1999).

${ }^{\mathrm{x}}$ See Auerbach et al., 1991 and 1994, and Kotlikoff, 1992.

${ }^{x i}$ Recent generational accounting studies are based on more sophisticated assumptions. For example, Gokhale, Page and Sturrock (1999) use official projections of the US Congressional Budgetary Office to forecast living generations' accounts.

${ }^{\text {xii }}$ If $\pi_{F}^{i}>1$, it indicates that the current policy cannot be applied to both living and future generations without a budgetary adjustment.

xiii The detailed data sources and the regional shares in public finance aggregates can be found in Beine et al. (1998) or in Cattoir and Docquier (1999).

${ }^{\text {xiv }}$ More precisely, the estimated 1999 surplus amounts to $6.0 \%$ of the national GDP for the federal budget and $0.16 \%$ of the national GDP for the Regions and Communities' budgets.

${ }^{\mathrm{xv}}$ The income tax per capita has been about $17 \%$ lower in Wallonia for the past ten years.

${ }^{\mathrm{xvi}}$ Brussels contributes for $19.1 \%$ to the national GDP for a population share of $9.2 \%$.

${ }^{x v i i}$ These assumptions are consistent with the Belgian generations' accounts computed in Dellis and Lueth (1998). The value of the interest rate may appear too large. However, combining profits on assets and net interest rates, Feldstein (1995) shows that the pretax real return to capital in the non financial corporate sector averaged 9.3\% between the sixties and the mid-nineties. Results for various other discount rates and growth rates are shown in the appendix.

xviii See Beine et al. (1998) for detailed results.

xix The figures presented here are partly based on optimistic assumptions. Indeed, we consider that the (growthcorrected) primary public consumption per capita will be constant for current generations for the rest of their lifetime while it is commonly accepted that the cost of pensions for civil servants will increase in the next decades, increasing the true debt left to future generations.

${ }^{\mathrm{xx}}$ This amount is close to the one presented in Dellis and Lueth (1998): using data for 1995, they estimated the average Belgian generational account at about Euro 30,000. Our national average is higher given the fact that we consider general public consumption as a private transfer (splitted equally between residents).

${ }_{\text {xxi }}$ Computing the Belgian generational accounts for the year 1995, Dellis and Lueth (1998) found that the lifetime net transfer should decrease by about $33 \%$ between living newborns and future generations. Our optimistic result is due to the evolution of the Belgian budgetary policy during the nineties. In 1999, the global budget deficit (including interest charges) amounted to $0.6 \%$ of the GDP compared to $4.4 \%$ in 1995 . This explains why the Belgian government has succeeded in restoring generational balance.

${ }^{\text {xxii }}$ However, it should be stressed that the results for the FG-rule are very sensitive to the assumptions made as to the discount and the growth rates (see the appendix). Since the debt-shares depend on a ratio of generational accounts, when the generational accounts used in the denominator are close to zero any small change in the parameters leads to tremendous changes in the results. This is precisely the case for the FG-rule in the Belgian context. 